\title{
A Bibliometric Analysis and Visualisation of Research Trends in Toxicity of Cobalt Implants
}

\author{
Gurjit Singh ${ }^{a}$ \\ Department of Mechanical Engineering, Chandigarh University, Gharuan, Punjab, \\ India. 140413
}

Article History: Received: 11 January 2021; Accepted: 27 February 2021; Published online: 5 April 2021

\begin{abstract}
The toxicity of metals is a vital factor affecting the safety of implants. The bibliometric analysis had been conducted to understand the active authors, organizations, journals, and countries involved in the research domain of "toxicity of Cobalt implants". All published articles related to "toxicity of Cobalt implants" from "Scopus", were analyzed using the VOS viewer to develop analysis tables and visualization maps. This article had set the objective to consolidate the scientific literature regarding "toxicity of Cobalt implants" and also to find out the trends related to the same. The most active journal related to this research domain was the Journal of Bone and Joint Surgery. The most active country was the United States of America. The leading organization was Rush University Medical Center, United States of America. The most active authors were Hallab N. J and Jacobs J.J.
\end{abstract}

Keywords: Toxicity of implants, Cobalt implant, Material engineering, Bibliometric analysis, VOS viewer,

\section{Introduction}

The toxicity of metals is a serious issue associated with metal implants and the impact of toxicity may be of varying degrees to different patients (Akil et al., 2018). The toxicity of Cobalt implants may be due to corrosion, wear, and or due to hypersensitivity to the metal. Toxicity and metal hypersensitivity at an extreme stage may even lead to failure of implant or replacement of implant with a comparatively safe metal. Different types of metals and materials are used to create implants and the most popularly used metals and alloys for bio-implants are stainless steel, cobalt-chromium alloy, and Titanium(Priyanka et al., 2014). Various types of implants had been used in modern medicine and include sensory implants, neurological implants, cardiovascular implants, orthopedic implants, contraceptive implants, and cosmetic implants. According to a recent study, the toxicity and health issues associated with Cobalt implants are severe than the implants based on Titanium and Zirconium (Dalal et al., 2012). Toxicity of Cobalt implants may lead to ophthalmological issues ( $\mathrm{Ng}$, Ebneter and Gilhotra, 2013) and Neuropsychiatric symptoms (Green, Griffiths and Almond, 2017). Similarly high level of Serum Cobalt concentrations due to Cobalt toxicity can also raise other health issues (Tolan, Sierra and Moyer, 2015) (Ng, Ebneter and Gilhotra, 2013).

Despite having various advantages associated with implants, the safety of implants is an important parameter associated with acceptance. The toxicity of implants and treatments to reduce the toxicity of implants is an important matter to be addressed. Material engineering and surface engineering play a vital role in the selection and usage of safe metals and alloys as implants. Serious health issues due to corrosion and wear of metal-metal implants based on Cobalt and Chromium (Campbell and Estey, 2013)(Cobb and Schmalzreid, 2006) Implants derived Cobalt-Chromium and molybdenum (CoCrMo alloy) nanoparticle disrupts DNA replication dynamics in neuronal cells (Bijukumar et al., 2021) Toxicity and allergy due to implants based on cobalt-chromium alloys (Posada et al., 2015);(Posada, Tate and Grant, 2015).

This bibliometric analysis will be a useful platform for future researchers by realizing the top researchers, organizations, and countries involved in research regarding the hypersensitivity of Cobalt based-implants. This article is arranged into four sections. The first section is the introduction, followed by the discussion of the methodology by which the research was conducted. The third section deals with results and discussion. The fourth section deals with the conclusion. The following research objectives and research questions were framed for conducting bibliometric analysis systematically.

\subsection{Research Objectives}

a) To consolidate the literature regarding the toxicity of cobalt implants

b) To find out the trends related to research in toxicity of cobalt implants

\subsection{Research Questions}

a) Who are the active researchers working on the toxicity of cobalt implants?

b) Which are the main organizations and countries working on the toxicity of cobalt implants? 
c) Which are the main journals related to the toxicity of cobalt implants?

\section{Research Methodology}

Scopus files had been used for this article. For the article selection, the Boolean used was TITLE-ABS-KEY (Toxicity Cobalt Implants) on 03/03/2021. All the tables in this paper were created by using Microsoft Excel and VOS Viewer. Grammarly was used for spelling and grammar checks. Mendeley was used for article review and citation. This paper had been inspired by bibliometric analysis in its presentation style, analysis, and methodology from the works (Farhat et al., 2013; Liao et al., 2016; Kolkailah et al., 2019; Rodríguez-Padial et al., 2019; Tran et al., 2019; Ullah et al., 2019; Shahid et al., 2020).

\section{Results and discussion}

\subsection{Results}

This first round of search produced an outcome of 128 documents, in six languages, out of which 120 documents were in English. The classification of document categories is shown in Figure 1. For improving the quality of the analysis, we had selected only the peer-reviewed articles and all other documents had not been considered. Thus after using filters "Article" and "English" the second round search produced an outcome of 89 English articles (both open access and others) and had been used to conduct bibliometric analysis and visualization using VOS Viewer. The English research articles in this domain since 1984 had been shown in Figure 2.

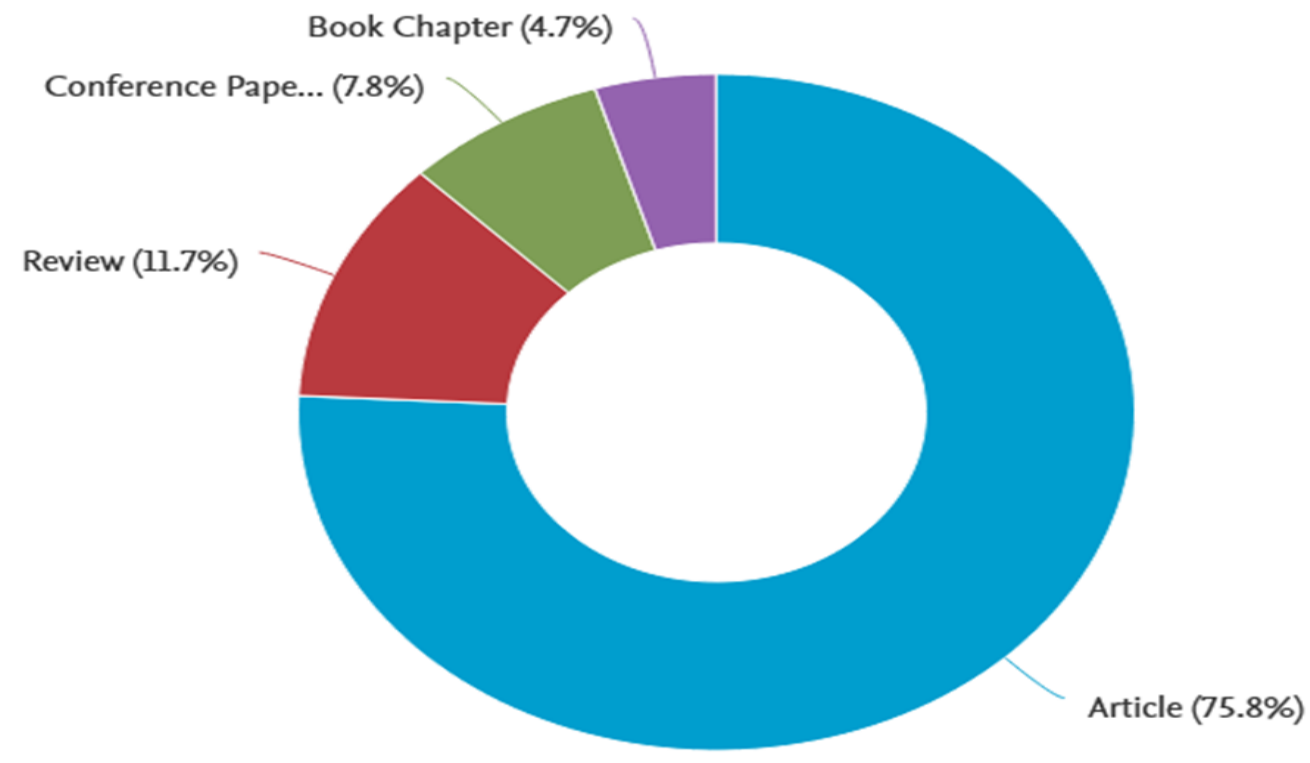

Figure 1: Classification of the documents on "Toxicity of Cobalt implants", Source: www.scopus.com

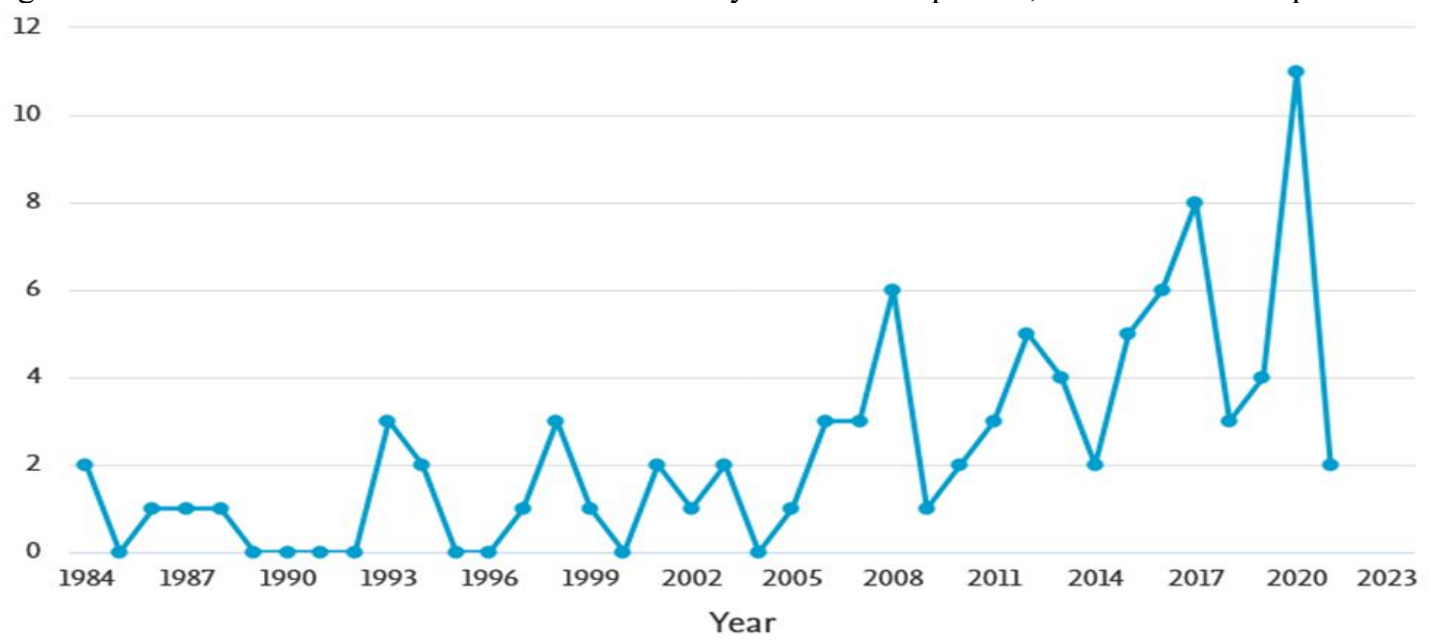

Figure 2: Period wise publication of articles, Source: WWW.scopus.com

Co-authorship analysis of top authors had been shown in figure 3. For a better presentation of the analysis, the parameters used were the minimum number of documents of an author as two and the minimum number of citations of authors as one. This combination plotted the map of 40 authors, in 11 clusters. The overlay visualization map of co-authorship analysis plotted in Figure 3, points out the major researchers with their strong co-authorship linkages and clusters involved. 


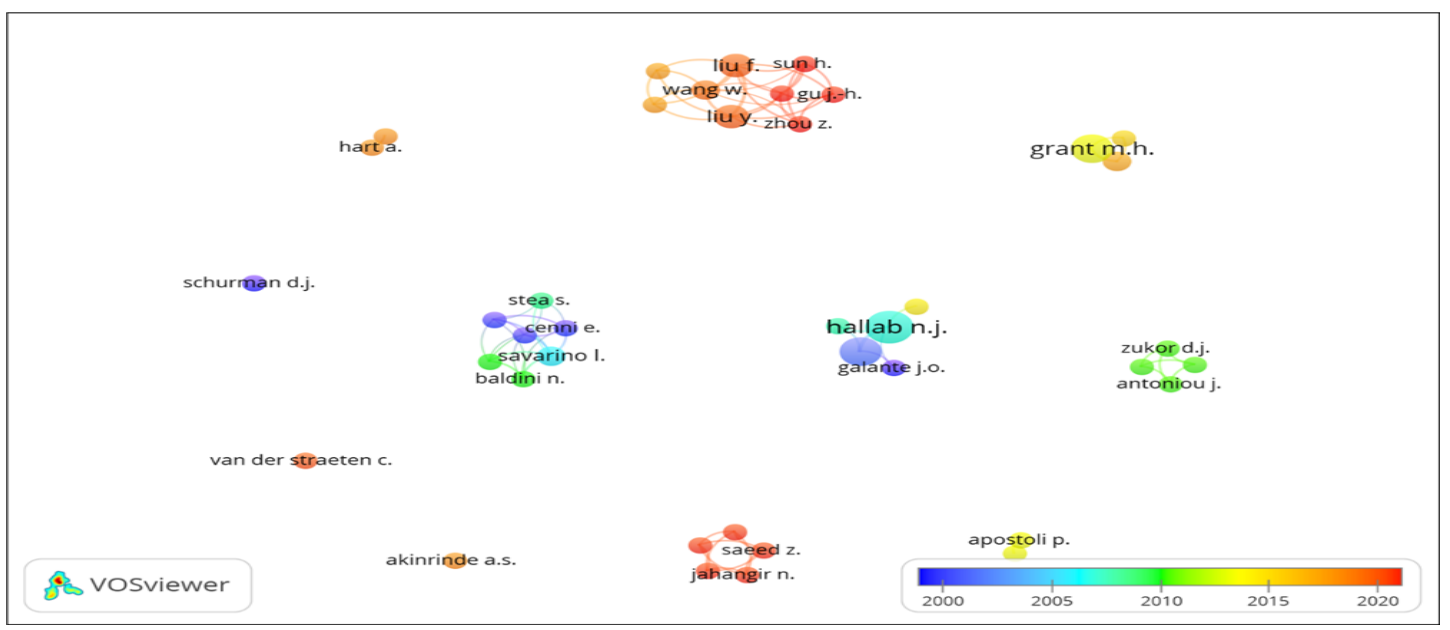

Figure 3: Co-authorship analysis on basis of authors

The citation analysis of top authors had been shown in table 1, along with co-authorship links. For the citation analysis, the parameters used were the minimum number of documents of an author as one and the minimum citations of an author as one.

Table 1: Highlights of most active authors

\begin{tabular}{|c|c|c|c|c|c|}
\hline Description & Authors & Documents & Citations & $\begin{array}{c}\text { Average } \\
\text { citations per } \\
\text { documents }\end{array}$ & $\begin{array}{c}\text { Link } \\
\text { strength }\end{array}$ \\
\hline $\begin{array}{c}\text { Authors with the } \\
\text { highest publication and } \\
\text { co-authorship links }\end{array}$ & Hallab N. J & 8 & 904 & 113 & 27 \\
\hline $\begin{array}{c}\text { Authors with the } \\
\text { highest citations }\end{array}$ & Jacobs J.J & 6 & 1072 & 178.6 & 20 \\
\hline
\end{tabular}

In Co-occurrence analysis, we had used all keyword analyses, by keeping the minimum number of occurrences of a keyword as 12. This combination plotted the map of 28 thresholds, in two clusters. The overlay visualization of co-occurrence analysis of keywords has been shown in Figure 4.

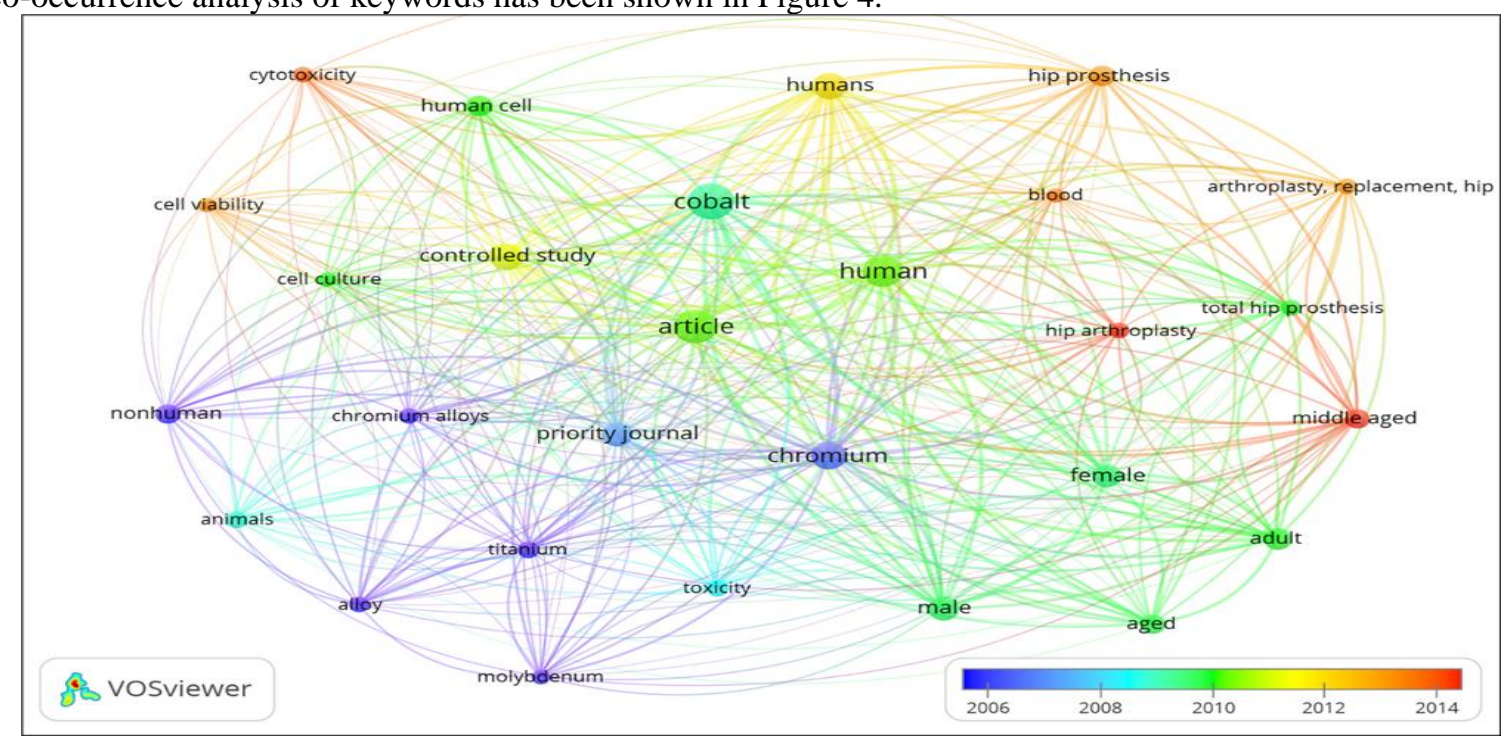

Figure 4: Co-occurrence analysis on basis of all keywords

The leading organizations engaged in research on the "toxicity of Cobalt implants" had been found out by the volume of publications and citation analysis, the parameters used are the minimum number of documents of an organization as one and the minimum number of citations of organizations as one. The leading organization in the 
research regarding the "toxicity of Cobalt implants", with the highest number of publications and citations, was the Rush University Medical Center, United States of America. (Refer to table 2).

Table 2: Highlights of the most active organization

\begin{tabular}{|c|c|c|c|c|}
\hline Organizations & Country & $\mathrm{s}$ Document & Citatio & $\begin{array}{l}\text { Average } \\
\text { Citations } \\
\text { per } \\
\text { document }\end{array}$ \\
\hline Rush University Medical Center & $\begin{array}{c}\text { United States } \\
\text { of America }\end{array}$ & 9 & 915 & 101.7 \\
\hline
\end{tabular}

Co-authorship analysis of the countries engaged in the research on "toxicity Cobalt of implants" had been shown in Figure 5. The overlay visualization map of co-authorship analysis plotted in Figure 5, points out the main countries with their strong co-authorship linkages and clusters involved.

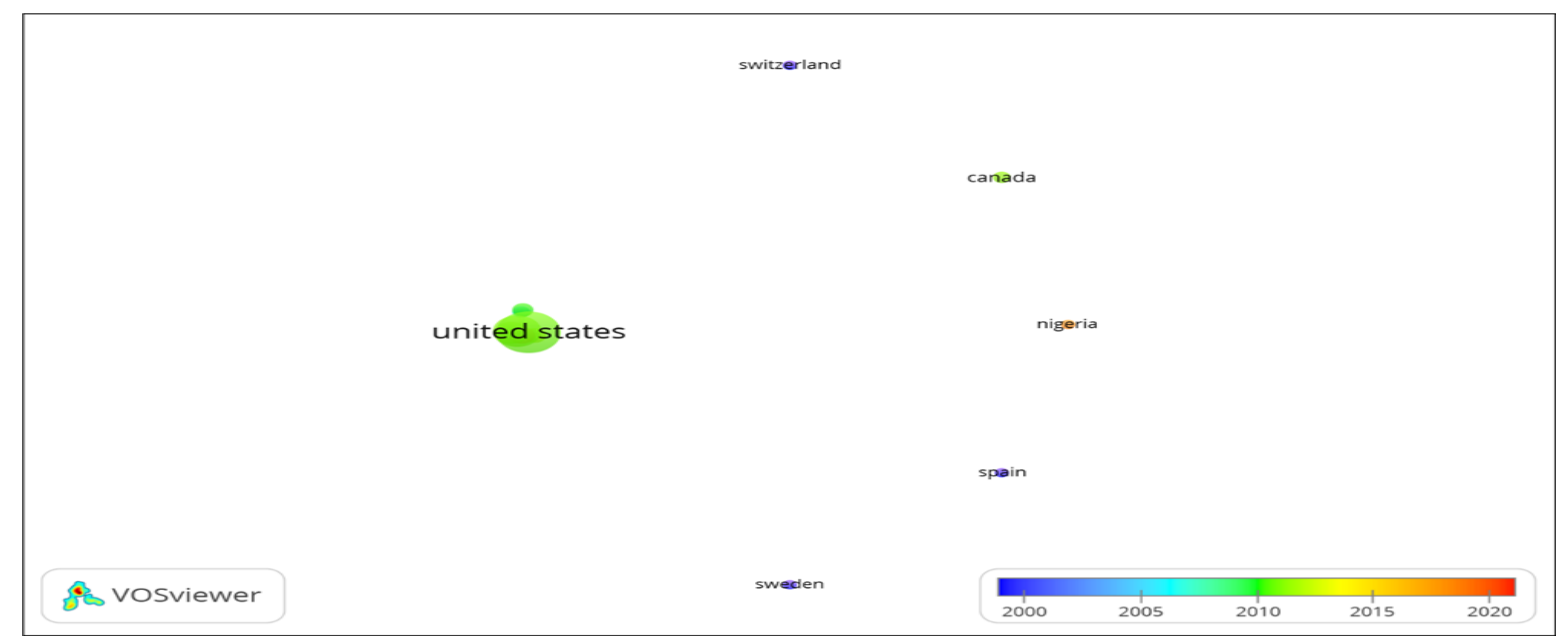

Figure 5: Co-authorship analysis on basis of countries

The citation analysis of top countries had been shown in table 3, along with co-authorship links. For the citation analysis, the parameters used were the minimum number of documents of a country as one and the minimum citations of the country as one.

Table 3: Highlights of Active Countries

\begin{tabular}{|c|c|c|c|c|}
\hline Description & Country & Document & Citation & Link strength \\
\hline $\begin{array}{c}\text { The country with the } \\
\text { highest publication, v and co- } \\
\text { authorship links }\end{array}$ & $\begin{array}{c}\text { United States of } \\
\text { America }\end{array}$ & 36 & 1971 & 10 \\
\hline
\end{tabular}

The most active country in this research domain was the United States of America, with the highest number of publications and citations; and co-authorship links.

Link analysis and citation analysis were used to identify the most active journal in this research domain. We have taken the parameters of the minimum number of documents of a journal as one and the minimum number of citations of a journal as one for the link analysis and citation analysis. Highlights of the most active and relevant journals related to "toxicity of Cobalt implants" are shown in table 4 . Table 4 shows the journal activity of this research domain through parameters of publication volume, citations, and co-authorship linkages.

Table 4: Analysis of journal activity

\begin{tabular}{|c|c|r|r|r|}
\hline Description & Journal details & Documents & Citations & \multicolumn{2}{c|}{$\begin{array}{c}\text { Average } \\
\text { citations } \\
\text { documents }\end{array}$} \\
\hline $\begin{array}{l}\text { Journal with the } \\
\text { perghest publications, } \\
\text { citations, and co- } \\
\text { authorship links }\end{array}$ & $\begin{array}{c}\text { Journal of Bone and } \\
\text { Joint Surgery }\end{array}$ & & & \\
\end{tabular}

From the above discussion regarding the bibliometric patterns in the research regarding "toxicity of Cobalt implants", this research had observed a gradual increase in research interest regarding "toxicity of Cobalt implants" from the starting of the millennium and the momentum is going on positively. This points out the relevance and potential of this research domain (Refer to Figure 2). The most active authors in this research domain were Hallab N. J and Jacobs J.J. with the highest publication and co-authorship; and citation respectively (Refer to table 1). The overlay analysis of top countries researching "toxicity of Cobalt implants" indicates that the United States of 
America was the leading country relating to the highest number of publications, citations, and co-authorship links (Refer to figure 5). The top journal of this research domain was identified as the Journal of Bone and Joint Surgery with the highest publication, citations, and co-authorship links. From these wide sources of information, researchers can focus on top journals where they can identify the most relevant and highly cited articles regarding the toxicity of Cobalt implants.

\section{Conclusion}

The toxicity of Cobalt implants was an interesting research domain and the most active journal related to this research domain was the Journal of Bone and Joint Surgery. The most active country was the United States of America. The leading organization was Rush University Medical Center, United States of America. The most active authors who had made valuable contributions related to the toxicity of Cobalt implants were Hallab N. J and Jacobs J.J. with the highest publication, citations, and co-authorship links. This research domain offers a new avenue for researchers and future research can be on innovations in the toxicity of Cobalt implants.

\section{References}

1. Akil, S. et al. (2018) 'Metal hypersensitivity in total hip and knee arthroplasty: Current concepts', Journal of Clinical Orthopaedics and Trauma, 9(1), pp. 3-6. doi: 10.1016/j.jcot.2017.10.003.

2. Bijukumar, D. et al. (2021) 'Implant-derived CoCrMo alloy nanoparticle disrupts DNA replication dynamics in neuronal cells', Cell Biology and Toxicology. doi: 10.1007/s10565-020-09577-7.

3. Campbell, J. R. and Estey, M. P. (2013) 'Metal release from hip prostheses: Cobalt and chromium toxicity and the role of the clinical laboratory', Clinical Chemistry and Laboratory Medicine, 51(1), pp. 213-220. doi: 10.1515/cclm-2012-0492.

4. Cobb, A. G. and Schmalzreid, T. P. (2006) 'The clinical significance of metal ion release from cobaltchromium metal-on-metal hip joint arthroplasty', Proceedings of the Institution of Mechanical Engineers, Part H: Journal of Engineering in Medicine, 220(2), pp. 385-398. doi: 10.1243/09544119JEIM78.

5. Dalal, A. et al. (2012) 'Orthopedic implant cobalt-alloy particles produce greater toxicity and inflammatory cytokines than titanium alloy and zirconium alloy-based particles in vitro, in human osteoblasts, fibroblasts, and macrophages', Journal of Biomedical Materials Research - Part A, 100 A(8), pp. 2147-2158. doi: 10.1002/jbm.a.34122.

6. Farhat, T. et al. (2013) 'Research in congenital heart disease: A comparative bibliometric analysis between developing and developed countries', Pediatric Cardiology, 34(2), pp. 375-382. doi: 10.1007/s00246-012-0466-6.

7. Green, B., Griffiths, E. and Almond, S. (2017) 'Neuropsychiatric symptoms following metal-on-metal implant failure with cobalt and chromium toxicity', BMC Psychiatry, 17(1). doi: 10.1186/s12888-0161174-1.

8. Kolkailah, A. A. et al. (2019) 'Bibliometric Analysis of the Top 100 Most Cited Articles in the First 50 Years of Heart Transplantation', American Journal of Cardiology, 123(1), pp. 175-186. doi: 10.1016/j.amjcard.2018.09.010.

9. Liao, J. et al. (2016) 'The most cited articles in coronary heart disease: A bibliometric analysis between 1970 and 2015', International Journal of Cardiology, 222, pp. 1049-1052. doi: 10.1016/j.ijcard.2016.08.002.

10. Ng, S., Ebneter, A. and Gilhotra, J. (2013) 'Hip-implant related chorio-retinal cobalt toxicity', Indian Journal of Ophthalmology, 61(1), pp. 35-37. doi: 10.4103/0301-4738.105053.

11. Posada, O. M. et al. (2015) 'In Vitro analyses of the toxicity, immunological, and gene expression effects of cobalt-chromium alloy wear debris and co ions derived from metal-on-metal hip implants', Lubricants, 3(3), pp. 539-568. doi: 10.3390/lubricants3030539.

12. Posada, O. M., Tate, R. J. and Grant, M. H. (2015) 'Toxicity of cobalt-chromium nanoparticles released from a resurfacing hip implant and cobalt ions on primary human lymphocytes in vitro', Journal of Applied Toxicology, 35(6), pp. 614-622. doi: 10.1002/jat.3100.

13. Priyanka, P. et al. (2014) Role of nanogrooves on the performance of ultra-fine grained titanium as a bioimplant, Advanced Nanomaterials: Synthesis, Properties, and Applications. Apple Academic Press. doi: 10.1201/b16966.

14. Rodríguez-Padial, L. et al. (2019) 'Trends and Bibliometric Impact of Research Grants of the Spanish Society of Cardiology/Spanish Heart Foundation (2007-2012) [Evolución e impacto bibliométrico de las becas de la Sociedad Española de Cardiología/Fundación Española del Corazón en el periodo’, Revista Espanola de Cardiologia, 72(12), pp. 1012-1019. doi: 10.1016/j.recesp.2018.08.013.

15. Shahid, I. et al. (2020) 'Characteristics of highly cited articles in heart failure: A bibliometric analysis', Future Cardiology, 16(3), pp. 189-197. doi: 10.2217/fca-2019-0016.

16. Tolan, N. V, Sierra, R. J. and Moyer, T. P. (2015) 'Evidence against implant-derived cobalt toxicity: Case report and retrospective study of serum cobalt concentrations in an orthopedic implant population', Clinical Biochemistry, 48(3), pp. 130-134. doi: 10.1016/j.clinbiochem.2014.10.012. 
17. Tran, B. X. et al. (2019) 'The current research landscape of the application of artificial intelligence in managing cerebrovascular and heart diseases: A bibliometric and content analysis', International Journal of Environmental Research and Public Health, 16(15). doi: 10.3390/ijerph16152699.

18. Ullah, S. et al. (2019) 'Publication trends of Pakistan Heart Journal: A bibliometric study', Library Philosophy and Practice, 2019. 